University of Nebraska - Lincoln

DigitalCommons@University of Nebraska - Lincoln

Faculty Publications: Agricultural Leadership, Education \& Communication Department
Agricultural Leadership, Education \& Communication Department

January 2005

\title{
Becoming a Professional Engineering Educator: A New Role for a New Era
}

\author{
L. Dee Fink \\ University of Oklahoma \\ Susan Ambrose \\ Carnegie Mellon University \\ Daniel W. Wheeler \\ University of Nebraska - Lincoln, dwheeler1@unl.edu
}

Follow this and additional works at: https://digitalcommons.unl.edu/aglecfacpub

Part of the Other Public Affairs, Public Policy and Public Administration Commons

Fink, L. Dee; Ambrose, Susan; and Wheeler, Daniel W., "Becoming a Professional Engineering Educator: A New Role for a New Era" (2005). Faculty Publications: Agricultural Leadership, Education \& Communication Department. 38.

https://digitalcommons.unl.edu/aglecfacpub/38

This Article is brought to you for free and open access by the Agricultural Leadership, Education \& Communication Department at DigitalCommons@University of Nebraska - Lincoln. It has been accepted for inclusion in Faculty Publications: Agricultural Leadership, Education \& Communication Department by an authorized administrator of DigitalCommons@University of Nebraska - Lincoln. 


\section{Becoming a Professional Engineering Educator: A New Role for a New Era}

\author{
L. DeE FINK \\ Instructional Development Program \\ University of Oklaboma
}

SUSAN AMBROSE

Eberly Center for Teaching Excellence

Carnegie Mellon University

DANIEL WHEELER

Ag Leadership, Education and Communication

University of Nebraska - Lincoln

\section{ABSTRACT}

Engineering education faces significant challenges as it seeks to meet the demands on the engineering profession in the twentyfirst century. Engineering faculty will need to continue to learn new approaches to teaching and learning, which in turn will require effective professional development for both new and experienced instructors alike. This article explores approaches to effective professional development and provides a conceptual framework for responding to the challenge of becoming a professional engineering educator. The "cycle of professional practice" is introduced as a prelude for identifying what individual professors and their institutions can do to generate more powerful forms of engineering education. The article concludes with two case studies that illustrate the possibilities when faculty and academic leaders join together in addressing calls for change.

Keywords: faculty development, professional development, engineering education

\section{INTRODUCTION}

In the first half of the twentieth century, engineering education focused primarily on the application of techniques. Laboratory problems were constructed with practical problems in mind. Following World War II, engineering educators realized that their students needed more than techniques; they needed to understand the science underlying the techniques. This led to curricula that included more science courses and a greater focus on theoretical problems [1]. During the last decade of the twentieth century, however, calls emerged for yet another round of major reforms and a new kind of engineering education. In this article we first discuss the need for a new kind of engineering education. We then discuss how individual engineering educators can respond and how institutions can support their effort, and we present two case studies that illustrate how individual and institutional efforts can improve engineering education. We conclude by proposing some directions for research and other actions in professional faculty development.

\section{The Challenge}

The mid- to late 1990s produced a number of now well-known reports calling for reform not only of engineering education [2-6], but also of undergraduate education at our nation's research universities [7]. The titles themselves convey a consistent message of the need for major educational transformation: Engineering Education for a Changing World; Engineering Education: Designing an Adaptive System; Restructuring Engineering Education: A Focus on Change; Shaping the Future; Transforming Undergraduate Education in Science, Math, Engineering and Technology; and Reinventing Undergraduate Education. These reports call for curricula that are relevant to the lives and careers of students, attractive to all types of students, and connected to the needs and issues of the broader community [2]. They call for curricula that include integrated and experiential activities and early exposure to engineering [2-4]; provide an interdisciplinary perspective [3-5]; address different learning styles [2-5]; focus more explicitly on skills such as problem-solving, communication, team and leadership, and life-long learning [2-5]; emphasize the social, economic and, environmental impact of engineering decisions [2-4]; take a systems approach [2, 3]; stress design [3, 4]; and incorporate ethics [2]. Further, they call for these changes to be informed by cognitive science and educational research [3] and to educate students for life by helping them learn how to learn [2-4].

These are significant challenges. They remind us that students and their learning should be the focus of the educational process [4]. They require a redesign of the curricula, courses, and classroom pedagogy in ways that cause us to reframe the roles of faculty and students in the educational process [8-12], i.e., to rethink our "mental model" of teaching and learning [3-5]. Similarly, these challenges cause us to reframe our thinking about the importance of institutional support. For example, a recent National Research Council report called for universities to create both general and discipline-based teaching and learning centers to support faculty in the creation of innovative courses and pedagogy [6, p. 9]. In the end, however, the individual engineering educator must take the initiative, and institutions must support and value these individual efforts.

\section{The Cycle of Professional Practice}

In their work as researchers, consultants, and professional engineers, engineering faculty follow a pattern of practice we call the 
"cycle of professional practice" (Figure 1 (a)). In this cycle, engineering faculty continually expand their technical knowledge and develop new competencies. Their work involves identifying, modeling, and analyzing engineering problems; generating, implementing, and evaluating solutions; and disseminating their work in the engineering literature [13]. Over time, this process leads to greater technical knowledge and better practices within the engineering community. This is the means by which engineering faculty traditionally further their technical professional development.

The cycle of professional practice is equally applicable to address the challenges facing engineering education where the focus is to solve educational problems rather than engineering problems (Figure 1 (b)). Thus, the cycle begins by first identifying the educational problems. The generation, implementation, and evaluation of solutions should take advantage of the body of knowledge in the cognitive sciences and educational research [3] as well as knowledgeable educational experts, a resource often found in campus teaching and learning centers [6]. The cycle concludes by disseminating the results so that they may be adapted and used by others. Through this cycle of professional practice, engineering faculty members can create a new and more powerful form of engineering education.

\section{IV.Three StAges of DeVELOPMENT}

"Expert teachers" possess knowledge in three areas: content knowledge (i.e., their disciplinary expertise), pedagogical knowledge (e.g., how students learn, what types of pedagogy are most effective for certain learning goals), and pedagogical-content knowledge (e.g., how to recognize and correct students' misconceptions in the domain, how to demonstrate procedures and methods used in the discipline, how to explain particular concepts within the content area). However, expertise in any domain is developed through years of practice (ten years is the often-cited number [14-16]) and teaching is no different. It is a skill that can be learned and improved with the right information, appropriate practice, and directed feedback [16-18]. An increasing number of engineering educators are sharing valuable approaches, strategies, and techniques on teaching and learning [19-28].

The focus of this paper, however, is not about teaching techniques. Instead, its purpose is to offer a new way to think about the development of the professional engineering educator. In some respects we focus on meta-cognition, that is, we focus on the cognitive processes that faculty follow as they learn more about teaching [8]. In this regard, they often work their way through three increasingly sophisticated stages of development.

\section{A. Enhance Common Teaching Techniques}

When faculty members begin teaching and observe things they deem problematic, e.g., students not attending class, not doing the homework, not understanding the material, or not performing well on exams, their first response is often to work on improving their teaching techniques, i.e., to learn more about the nuts and bolts of teaching. At this stage faculty might ask how they can make their lectures more interesting and engaging, how they can write better exams, or how they can best use technology to enhance their lectures $[29,30]$.

There is much to learn about teaching techniques. However, at some point, many faculty realize that no matter how well they

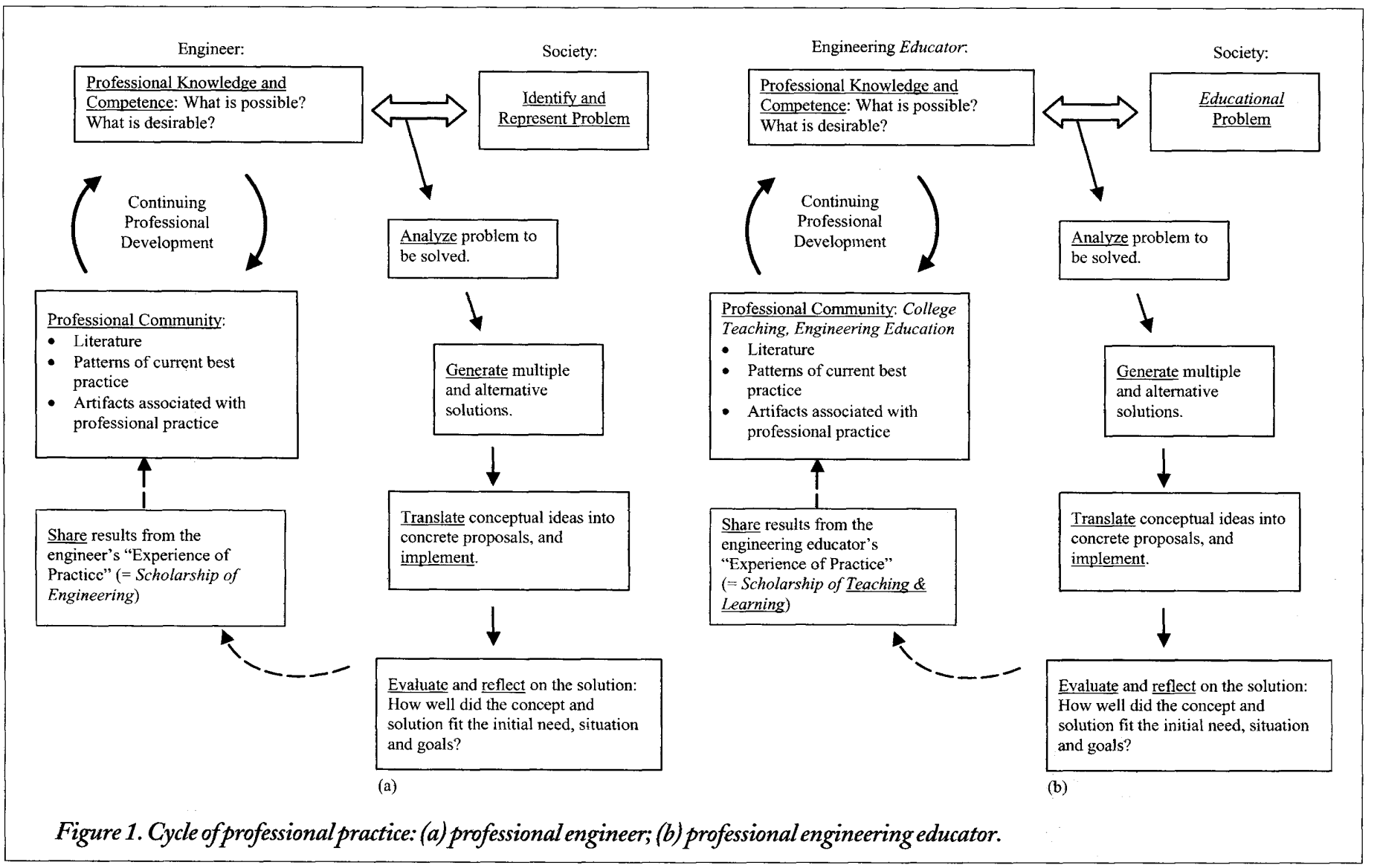


lecture or write their exams, a gap still exists between student performance and faculty expectations. When this happens, faculty often move to the next level: examining what constitutes effective teaching, what defines deep-level learning, and what characterizes appropriate faculty and student roles in the process.

\section{B. Understand the Science and Principles of Learning and Teaching}

While learning more about teaching techniques helps instructors to be more effective at what they are already doing, understanding the principles of learning and how they impact teaching can help them create new and more powerful forms of learning. In other words, the problem may not be that the instructor is a poor lecturer, but rather that lecturing is not the best way to engage students in the learning process.

Initial inquiries on the principles of learning may focus on fundamental issues: how people learn $[18,31]$, how students process information [32], how prior knowledge affects learning, what we know about the impact of organization on the ability to retrieve and use information flexibly $[13-15,17,18]$, or on the varied ways that different individuals learn [31-37]. Following naturally from these more general issues are more specific questions about learning goals, including what different kinds of knowledge would constitute significant learning for students. For example, psychologists have distinguished among declarative knowledge (define and describe), procedural knowledge (how learners use or apply declarative knowledge), structural knowledge (how concepts in a domain are interrelated), and contextual knowledge (when to access certain principles or concepts and when to use certain procedures) [37]. Different taxonomies of learning exist that can help faculty more clearly define measurable goals that can then guide the design of courses [38-40]. Defining goals inevitably leads to a discussion of both how to achieve those goals (in and out of class activities) and how to measure whether students have met those goals. In this vein, faculty often ask what "active learning" really means and why research indicates that the more active the students are the deeper their understanding will be. They want to know, for example, how and why specific kinds of learning activities help students facilitate the storage of information in long-term memory and create a stronger representation and multiple avenues for retrieval [18, 34, 41-44].

Because goals and learning activities must be aligned with assessment [45], at this stage consultants and faculty often discuss how to create assessment activities that support high-quality student learning (rather than just giving a basis for assigning grades), what is often referred to as educative assessment [46]. This includes decisions on how to provide information on students' strengths and mastery of material, as well guidance on how to improve understanding and performance. Students need feedback on their learning that allows them to grow as learners and sharpens their understanding of specific subject matter. This feedback can come from the teacher, other students, and their own self-reflection [46-48].

Another important aspect of effective teaching is to integrate the major components of a course (learning goals, teaching/learning activities, feedback, and assessment) [38]. These three components need to support and reflect each other in a coherent teaching strategy. That is, the combination and sequence of learning and assessment activities should build energy, engage students, and allow the learning to develop and grow stronger as the course proceeds. An educator can create his or her own teaching strategy or adopt a general teaching strategy. Two general strategies that many educators have found valuable are team-based learning (TBL) [49] and problem-based learning (PBL) [50].

Engineering educators who become more knowledgeable about the learning process find that it allows them to engage in a higher order of problem solving. Instead of focusing on questions like "How can I improve my lectures?" they now explore questions like "How can I integrate and align active learning and assessment into my courses to generate more sophisticated and significant learning?"

However, even when an instructor develops and implements strategies that have proven to be effective, something may still be missing; the spark and energy of exciting teaching and learning may still not be there. When this happens, the instructor may need to explore the next level of learning.

\section{Explore the Humanistic Dimension of Education}

Ultimately, teaching is an action with a profound human dimension. Being a responsible contributor to this process requires that we try to understand our own - and our students'-passions, motivations, and life experiences. As basketball great Michael Jordan once said, "There is more to basketball than basketball," meaning that we have to understand ourselves, our teammates, and the other players, i.e., the human dimension of the game, to play well. Similarly, when professors pursue this dimension of teaching, there are a number of issues they can explore. They can ask themselves what unique "humanity" they bring to the teaching and how they can use that humanity to teach in an inspired and inspiring way. They explore ways to share their passion for their subject with students who are often very different from us, their teachers [51-54]. Instructors must ask how they can more fully understand and relate to students as human beings. Research indicates that this generation of students (sometimes called the "millennials") is very different from past generations, and to be effective instructors we need to understand how and why they are unique $[55,56]$. What (and how) can instructors learn about their students' potential and needs as human beings in a way that is appropriate to the role of an educator [57]?

At the apex of this dimension, teachers think about learning and life and what they can do to help students see the central role of learning in life (referring here to both course-based and life-based learning) $[58,59]$. An abundance of research clearly indicates that various dimensions of personal growth and change occur during a student's college experience and it also shows that educators impact this growth and development often without even realizing it [60, 61]. Educators should have an awareness of their "growth edges," i.e., those aspects of teaching where they feel uncertain and in need of new and better ideas to guide their actions.

An awareness that there is much to be learned can be both exciting and daunting. While the amount of information available can be overwhelming, the path to expertise is traversable and there are people, e.g., faculty developers, engineering colleagues, available to help with the journey.

\section{V.TEACHING AND LEARNING RESOURCES}

A survey by the SUCCEED Coalition in 1997-98 found that engineering faculty are interested and do participate in activities aimed at increasing their effectiveness as professional engineering educators [62]. Sixty percent of the respondents in that survey 
indicated a change in the way they teach as a result of their participation in SUCCEED workshops and seminars. Many colleges and universities have campus-based programs to help faculty develop as professional educators, and some colleges of engineering, as well as national organizations, have created centers and programs dedicated specifically to engineering education.

\section{A. Campus-Based Programs}

Beginning in the late 1960s, a number of institutions established on-campus programs to help faculty and/or graduate students learn about college-level teaching. Today it is estimated that approximately 25 percent of all institutions offering at least a four-year program have a teaching/learning center; nearly 60 percent of all research universities have one; and the total number of institutions with such programs is increasing each year [63]. Though program names vary-instructional development program, center for teaching excellence, center for teaching and learning - their goals and activities have a great deal in common.

Campus-wide faculty development programs have traditionally offered three types of services: individual teaching consultations, workshops, and support for personal development [64]. In individual consultations faculty members work with instructional consultants to plan and deliver teaching consistent with their goals and based on learning principles, their particular student population, the size of the class, the faculty member's style as a teacher, etc. The consultants help faculty examine what they want students to learn and then explore what materials, media, and teaching strategies will most effectively support their learning goals. Consultants also help faculty gather and analyze formative data early in a course so they can gauge what is working well and address what is problematic; consultants can help analyze and act on end-of-course student evaluations as well.

Most programs also offer workshops, which can be more resource efficient than individual consultations. These workshops may focus on a wide range of topics, such as systematically designing courses, creating active learning opportunities, designing effective grading procedures, understanding how students learn, and using instructional technology effectively - in essence, sharing information and showing the realm of possibilities. Some programs offer consultations or workshops focused on personal development as well, recognizing that dealing successfully with personal issues is likely to improve work performance. Faculty participants in these programs receive assistance with issues such as enhancing interpersonal skills, maintaining wellness, balancing work-life demands, and life-career planning [65].

During the last decade or so, some directors of faculty development programs have felt constrained by programs focused on meeting the needs of individual faculty members, i.e., those who voluntarily spent time and effort on becoming more effective teachers. In many cases, this was only 20 percent or so of the faculty. As an alternative, some programs directors have turned to one or both of the following strategies, usually in addition to traditional approaches.

The first strategy is to link program activities to institutional initiatives. Rather than asking what individual faculty members need, these programs take their cues from institutional initiatives, e.g., efforts to promote interdisciplinary learning, active learning, writing across the curriculum, or the use of instructional technology. They offer workshops or consultations based on these issues and often get greater faculty participation because there is greater administrative support and encouragement.
The second strategy is to work with administrators to make effective teaching and instructional development higher institutional priorities. Some faculty indicate they would like to participate in professional educational development but, in their view, the institution does not reward good teaching or learning about teaching [66]. Faculty who have this perception frequently decide to focus on activities that are rewarded, such as writing grant proposals, doing research, and writing for publication. To counter this tendency, some faculty developers work with chairs, deans, and provosts, encouraging them to reexamine the institution's infrastructure (especially the faculty incentive and reward structure) and the way it affects faculty behavior.

\section{B. Engineering Focused Programs}

Engineering is ahead of many other disciplines in efforts to improve education. During much of the 1990 s, there was considerable activity to improve engineering education. The Engineering Directorate of the National Science Foundation (NSF) funded seven Engineering Education Coalitions [67], multi-institutional collaborations that focused on designing, implementing, and assessing new approaches to undergraduate education. For example, the Synthesis Coalition promoted, among other things, the innovative use of technology, while the SUCCEED Coalition offered a coordinated faculty development program. NSF also funded, during this time, the Engineering Education Scholars Workshops, week-long programs aimed at helping new Ph.D. graduates transition more easily into teaching [68].

The 1990s also saw the creation of new centers focusing on engineering education, for example, the Center for Engineering Learning and Teaching (CELT) at the University of Washington, Seattle [69]. This center was one response to meeting the challenge of improving engineering education through both research in engineering student learning and faculty development (by sharing research findings). Others like it exist at the University of Illinois at Urbana-Champaign, Arizona State University, University of South Carolina, Georgia Institute of Technology, Purdue University, Pennsylvania State University, and the Colorado School of Mines, to name a few. More recently (2002), the National Academy of Engineering created the Center for the Advancement of Scholarship on Engineering Education (CASEE) to foster a climate of continuous improvement in engineering education by extending the research base on engineering education and translating research results into actual practice in the classroom [70].

In 2001, the NSF addressed the need to make engineering education scholarship more prestigious by announcing the first Director's Awards for Distinguished Teaching Scholars, awarding seven faculty members $\$ 300,000$ each over four years to continue and expand their work this field [71].

Besides these newer programs and centers, we must not forget the long history of the American Society for Engineering Education (ASEE), founded in 1893 to promote and improve engineering education [72]. More recently, the Frontiers in Education conferences began, also dedicated to promoting the widespread dissemination of innovation in engineering education [73]. Suffice it to say that support for enhancing engineering education goes well beyond college campuses.

\section{INSTITUTIONAL ROLE}

Colleges of engineering can excel at teaching and learning when the majority of their faculty develop and achieve a high level of 
professional pedagogical knowledge and competence. Achieving excellence requires administrative and faculty leadership.

\section{A. Promote Cultural Change}

Culture is typically defined as the common set of beliefs and values that create a shared interpretation and understanding of events and actions [74, 75]. Rousseau describes the major dimensions of culture as physical manifestations or material artifacts, patterns of behavior, behavioral norms, values, and fundamental assumptions [76]. Until recently many would argue that the culture of the academy, particularly at research institutions, includes valuing research more than teaching, which is what led Boyer in 1990 to propose four types of scholarship, including the scholarship of teaching [12]. For the reforms in engineering education advocated in this article and others in this issue to be enacted, the culture of engineering schools must continue to evolve to the point where the changes advocated (broad participation of engineering faculty in professional development activities) will be reinforced by an explicit set of expectations, a support structure, and a compatible faculty reward system.

1) Establish clear expectations of continuous growth as professional educators: When working to establish what may be a new expectation for faculty work, it helps to emphasize that the new activity is similar in character to what the faculty already do as researchers, consultants, and/or professional engineers, and that they are simply extending and applying an established pattern of professional practice to another major area of faculty responsibilities. This is the approach taken by two National Science Foundation Centers for Learning and Teaching (Center for the Advancement of Engineering Education and the Center for Integration of Research, Teaching and Learning) as well as the National Academy of Engineering's Center for the Advancement of Scholarship on Engineering Education.

2) Provide the necessary support services and learning opportunities: In the dialogue between administrators and faculty that is needed to bring about change, faculty will rightfully identify current barriers, including the need to make time for new activities ("What can we unload to make room for these things?"), the need for opportunities to learn (having access to workshops in the college, on the campus, or at professional conferences), authorization to experiment with new ways of teaching without risking low annual teaching evaluations initially, and access to instructional consultants and good teachers to serve as coaches and mentors.

These are legitimate questions and needs. Administrators and faculty leaders will have to search for creative ways of meeting these needs while continuing to address other institutional needs, doing research and providing service.

3) Assess and reward effective teaching and learning about teaching: As faculty members learn about and become competent with new ways of teaching, assessment of teaching effectiveness must go beyond a sole reliance on end-of-course student evaluations to the use of course materials, examples of student learning, etc. These enhanced definitions of effective teaching need to be incorporated into the criteria for annual evaluations and teaching awards. Another way to reward learning about teaching is to encourage and reward faculty who participate in the scholarship of teaching and learning. As faculty participate in the scholarship of teaching and learning, they can evaluate the impact and publish reports of their experiences in places like the Journal of Engineering Education or in journals on college teaching. Educational research may use methods that differ from the quantitative methods familiar in traditional engineering research, but it can be carried out and evaluated with the same standards of rigor [77] and should count in the same way toward promotion and tenure [78].

As engineering departments and colleges incorporate changes such as those outlined above with the goal of influencing faculty behavior and performance, they will-over time - see faculty grow as professional educators. However, to make and sustain such changes, administrative and faculty leaders will need to address a number of organizational issues as well.

\section{B. Enhance Leadership}

The above change in culture must be purposeful and can only happen with the support of academic leaders, including senior faculty, department heads, and deans. Attention must be paid to initiating and managing change. Two considerations are key: (1) align all procedures and decision-making groups and (2) learn how to initiate and sustain significant change efforts.

Many change models are available to encourage the kind of culture change that would lead to an increase in faculty development and an improvement in student learning. There is a robust literature that academic leaders can draw upon, as well as an increasing number of faculty development programs that now offer seminars for department heads and deans. This literature includes, for example, models of change $[79,80]$, recommendations on "culture-embedding mechanisms" [75], and factors that can help change people's minds [11], as well as advice on how leaders can make culture more explicit [75].

\section{Two CASE STUdies}

Thus far, we have argued that learning about teaching can result in better curricula and more effective teaching. But does professional educational development make a difference? Relatively little solid research exists that sheds light on this question, particularly in engineering education. However, one of the few published studies [62] demonstrates a direct link between faculty participation in teaching workshops and their use of the instructional methods the workshops taught and encouraged. There is clearly room for more research in this area. In the absence of such research, we offer two case studies that illustrate the possibilities.

\section{A. Carnegie Institute of Technology (CIT) at Carnegie Mellon University}

1) Discussions and decisions: During the late 1980s, the dean of engineering of the Carnegie Institute of Technology (CIT), with . strong support of department heads, initiated a series of facultywide discussions of the mission and structure of the undergraduate curriculum. These discussions culminated in a college-wide retreat in 1990 and a revamped curriculum that was launched in 1991.

The new curriculum reflected three major decisions. First, the college retained the requirement that eight courses (20 percent of the student's program) be in the humanities, social sciences, and fine arts to validate the importance of a broadly educated engineer. Second, "designated minors" were created as an option for students wanting more flexibility and diversity in their education. The third and most dramatic change was in the nature of the freshman year 
offerings, which were revised in the following ways:

- Each of the six engineering departments started teaching an introductory engineering elective course in both the fall and spring semester, and every freshman was required to take one such course each semester.

- Each of the introductory engineering electives was associated with a science or computer science course (technical electives) as a co-requisite.

- The total number of courses per semester was reduced from five to four in the freshman year.

2) Support: Recognizing that a major educational initiative of this magnitude required new pedagogical competencies (particularly since none of the engineering faculty had ever taught first-year undergraduate students), the dean asked for involvement from Carnegie Mellon's campus-wide faculty development center, the Eberly Center. The support included three complementary components.

The first was a set of workshops focused on teaching first-year engineering students, emphasizing the research on intellectual and social-emotional development and the transition into college. The workshops also addressed issues related to cognition, linking principles of learning to the design of courses, and classroom pedagogy. The dean and department heads encouraged attendance, and all faculty engaged in designing and teaching the freshmen courses attended.

While the workshops provided a new way to think about the educational process, the students, and the role of faculty members in the process, the second part of the process resulted in the greatest change. The Eberly Center staff worked with individual faculty members who were involved in designing the new courses [81]. In each case the consultation began with a discussion of audience characteristics, e.g., intellectual, experiential, socio-emotional, and how to use this information in course design. The discussion then moved to decisions of scope and content, e.g., breadth vs. depth, articulating measurable course goals, aligning course activities with those goals, planning deliberate practice and feedback opportunities, and aligning the assessment of the course goals with evaluative mechanisms. The workshops and the individual consultations were not new to most of the engineering faculty involved; the culture of the engineering college since the early 1980s had been to take advantage of the center's expertise as way to enhance the effectiveness and efficiency of teaching and learning.

In the third component of the program, the center staff observed faculty members during the first few weeks of classes and conducted focus groups with students to gather formative assessment data that was used to initiate change during the first few semesters. In five of the six departments involved, this formative assessment continued for two or three years until the faculty member honed the course to the desired level or passed it along to someone else.

3) Impact on teaching: Possessing new information about the learning process and a broader repertoire of skills, faculty made significant changes in the way they taught. Two examples illustrate the types of changes made.

In one case, a professor of electrical and computer engineering wrote measurable learning objectives and then carefully aligned these with the learning activities, e.g., lectures, labs, homework, and the assessment procedures. The alignment of these three parts of the process, i.e., goals, activities, and assessments, led to a rigorous course with high levels of student success indicated by course grades and through faculty reports of students' performance in subsequent courses.
In another case, two materials science professors utilized case studies in a quasi-problem-based learning approach. They gave students common items, e.g., running shoes, a Walkman ${ }^{\mathrm{TM}}$, to introduce them to the materials-related aspects of things they encountered on a daily basis. Students then analyzed the required properties, structure, and performance of the materials. Once students learned the basic protocol of analyzing materials for the selected applications, they were able to apply it to other cases. The course design worked in large part because the case materials were drawn from things that naturally intrigued eighteen year olds, and the teaching methodology lent itself to transfer across different materials.

4) Impact on students: CIT conducted extensive assessment of the impact of the new curriculum at the end of two five-year intervals. The assessments have been valuable because they identified achievements as well as areas that still need improvement. Some general conclusions:

- Student retention improved. Freshmen-to-sophomore retention increased from 80 percent (1990) to 92 percent (2000).

- Freshman-to-senior attrition declined from 20 percent to 16 percent.

- Student ratings of their courses and instructors improved; the college-wide average increased from 3.6 to 4.0 (on a scale 1 [low] to 5 [high]).

- Faculty members were surveyed about their impressions of students under the old and new curricula. In the eight areas of student learning included, faculty thought the new curriculum was working at least as well or, in most cases, better than the old one. They gave significantly higher ratings to two areas: written communication and knowledge of engineering practice.

The assessment effort thus far has focused on retention and satisfaction by students, recruiters, and alumni. Because the Eberly Center now has resources to help with more formal assessment of student learning, future efforts in CIT will focus on summative evaluation of student learning.

5) Conclusions: Significant changes were brought about through the leadership of the dean and department heads, appropriate support and resources, and faculty members' willingness to learn. All three are a result of a culture in the college that values effective undergraduate education and prides itself on a history of educational innovation.

\section{B. Second Case Study: Civil Engineering and Environmental Science (CEES) at the University of Oklahoma (OU)}

1) Initial administrative actions: In the late 1980s, the University of Oklahoma hired a new dean of engineering who was interested in promoting the kind of faculty development advocated in this article. He took several actions, including hiring a new director of CEES who shared this desire, establishing a policy to pay half of the expenses for faculty to attend conferences on engineering education, and bringing in workshop leaders on the same topic.

The new director of CEES held a retreat for CEES faculty to discuss the need for being active in engineering education. The availability of a growing number of education-related grant programs at NSF was an important factor in this discussion. The director also held an ongoing seminar for new faculty members that gave extensive attention to issues of curricula and teaching. 
At the retreat, faculty restructured the curricula to reduce the number of required courses. The reduced teaching load gave faculty the time to spend on engineering education. They also made three other notable changes. First, they changed the way they hire new faculty. Position descriptions now state the importance of educational responsibilities. During the interview process, faculty candidates teach a class, and reactions are solicited from the students. Second, in annual evaluations and in the promotion and tenure process, publications on teaching are considered equivalent to publications on regular engineering topics. Third, faculty recognized the need for assessment data on the quality of student learning in the division and have since systematically collected this data.

2) Results - Impact on faculty efforts to learn about teaching: Within a few years, the faculty culture in this division of engineering changed. It became the norm to participate in campus-based faculty development activities, to submit education-related grant proposals, and to attend engineering education conferences. Faculty continue to be productive in traditional forms of engineering scholarship. Of the fourteen full-time, tenured/tenure-track faculty in the division today:

- 100 percent have participated in at least one activity offered by OU's Instructional Development Program, and 70 percent have participated in more than one;

- 65 percent have attended conferences on engineering education, e.g., ASEE, Frontiers in Education, in the last four years; and

- 40 percent have contributed to the scholarship of teaching and learning, either through print publications or leading sessions at education conferences.

3) Results -Impact on faculty teaching: Essentially all of the current faculty are using one or more proven but nontraditional teaching practices, including authentic projects, reflective writing, significant learning goals, active learning, interdisciplinary projects, and creative forms of assessment. The Sooner City Project has been a major stimulus in the change process. With support from NSF, this project has created a curriculum in which students work in teams on challenging design projects, starting with their initial courses in engineering and continuing through the capstone course, with reflective writing about the learning process frequently included. The division is just now initiating an experimental course in which students will spend some time each year reflecting on and integrating their own learning experiences in engineering.

Since learning about teaching became part of the culture within the division, faculty $(\mathrm{N}=14)$ have received extensive recognition, both at OU and nationally. Six CEES faculty have been recognized with University of Oklahoma teaching and research awards, while two others have been honored regionally with the Oklahoma Regents Instructional Technology Excellence Award and the Oklahoma Williams Faculty Innovator Award. At the national level, CEES faculty members have earned six NSF CAREER Awards, an ASEE Fred Merryfield Design Award, three ASEE Dow Outstanding New Faculty Awards, and a National Society of Professional Engineers Design in Education Award. The work of many of these faculty has been featured in ASEE's Prism magazine, NSPE's "Engineering Times" newsletter, OU's "Spotlight on Teaching" newsletter, and numerous journal articles and conference presentations.

4) Results-Impact on student learning: The ultimate goal of changing engineering education is to change faculty practices to improve the quality of student learning. Students have indicated a high level of satisfaction since the changes have been implemented. In a questionnaire given to graduating seniors that focused on types of learning (e.g., lab experiences, technical writing, oral communication skills, team experiences, design skills), the overall mean rating was at the ninetieth percentile of satisfaction. In the section that focused on $\mathrm{ABET}$ engineering criterion $3(\mathrm{a}-\mathrm{k})$, more than half of the responses were in the 70 to 90 percent range; the other half were in the 60 to 70 percent range.

Evidence of student performance comes from the assessment of capstone projects. In a creative assessment effort that included level of difficulty as well as performance, students who participated in Sooner City improved their performance scores 33 percent during the last three years.

Changes in student competence are also reflected in the scores of graduating seniors on the NCEES "Fundamentals of Engineering" exam. Although these vary considerably from semester to semester, pass scores have increased from 60 to 80 percent in the early $1990 \mathrm{~s}$ to 70 to 90 percent in recent years [82].

A final perspective on changes in student learning comes from a professor who has taught in the division for more than fifteen years. His observation is that OU's graduates today are clearly better prepared for entry-level engineering work. "They are much better at critical thinking, have the big picture of engineering work, know how to engage in team work, can handle uncertainty, and know how to move forward in projects where they have only limited information" [83].

5) Conclusions: Several observations and conclusions can be drawn from this case study. First, change began with a particular kind of leadership and was supported by several kinds of organizational change. Second, once they had been given the encouragement and opportunity to engage in faculty development, faculty took advantage of available resources, both within the university and nationally. Third, once the culture of valuing good teaching was created within the division, the faculty made changes, both in the curriculum and within their individual ways of teaching. Altogether, these changes have resulted in significant improvements in student learning.

\section{SUMMARY}

The engineering profession is calling for new and better kinds of learning by engineering students. Accomplishing this requires new and better kinds of teaching and curricula, which in turn requires engineering faculty to think about teaching and learning in more scholarly ways. We conclude by answering two questions: What do we know about professional development of faculty and what else do we need to learn and do?

\section{A. What Do We Know?}

First, considerable research exists that can help us better understand students as cognitive and socio-emotional beings and provide us with teaching approaches that can effectively address their learning needs. This research can help guide a more effective design of engineering courses and classroom pedagogy. Second, we know that many engineering educators have already tapped into this research and use it successfully. Finally, we know that many engineering educators simply have not availed themselves of this research and its application. If we want to introduce meaningful change in how engineering education is practiced throughout the profession, 
faculty members will need a new perspective that validates why learning about teaching is important, i.e., motivation that comes from the culture, as well as opportunities to engage in what and bow to learn about teaching, e.g., a systematic way for continual educational development.

We also know a lot about what needs to happen at the institutional level to impact culture and introduce change in the perspectives and practice of engineering education. Leaving change up to individual faculty members without a supportive culture, e.g., without reward systems that value teaching as scholarship or opportunities for educational development, doesn't work. Piecemeal effortsa workshop here or an initiative there-may result in pockets of improvement but will not change the norms, values, and behaviors within the profession as a whole. What is necessary to create a change in culture is for the organization, i.e., the department or college, to have a comprehensive and integrated set of components: clearly articulated expectations, a reward system aligned with those expectations, and opportunities for the learning to occur.

Such a comprehensive and integrated approach was demonstrated in the two case studies presented earlier. In both cases, college and department leaders set clear goals for their educational programs and made changes in a set of college and departmental operations, e.g., procedures for recruiting faculty, changes in the curriculum, encouragement to participate in workshops on teaching and learning, and rewards for good teaching, learning about teaching, and the scholarship of teaching. In both cases, a new culture of faculty work emerged that emphasized quality teaching-and student learning improved as a result.

\section{B. What Else Do We Need To Do?}

What else do we need to do to continue along the road to better teaching and learning in engineering education? The situation calls for a combination of research, sharing of best practices, and selected national initiatives.

1. Research: Although we know that such things as active learning and new teaching strategies in general (e.g., problem-based learning) enhance student learning, we need to continue doing research on what it takes to make particular forms of teaching effective- in particular situations, with particular students, with different kinds of subject matter, etc. At another level, we know that faculty development activities in general are capable of enhancing faculty attitudes toward teaching and increasing their pedagogical skills. However, we need to continue research on what it takes for particular professional development activities to be effective in particular situations, with different kinds of faculty, etc.

2. Best practices: We also need to continue sharing information on creative and innovative practices in teaching, professional development programs, and departmental efforts to support better teaching, and we need to include evidence of impact.

3. National initiatives: Professional associations in higher education and in engineering need to continue thinking about what national initiatives could be mounted, perhaps with the participation of multiple organizations, that would encourage departments and colleges to make the organizational changes necessary to more effectively support better teaching and learning. Some exist now, but what else might be worthwhile? For example, is there a way to measure the quality of educational programs that would allow those institutions that have succeeded in creating high-quality programs to be recognized and rewarded for doing so?
If we can do the necessary research, share our best practices, and mount strategically important national initiatives, future generations of engineering students will have an educational experience of much higher quality, one that provides them with the knowledge, attitudes, and skills they need and provides society with first-rate solutions to increasingly important and complex engineering problems.

\section{ACKNOWLEDGMENTS}

We wish to acknowledge the invaluable assistance provided by Robert Knox, director of the Division of Civil Engineering and Environmental Science at the University of Oklahoma, and James Garrett, associate dean and professor of Civil and Environmental Engineering at the Carnegie Institute of Technology at Carnegie Mellon University, in assembling information for the two case studies in this article; and Richard Felder, Hoechst Celanese Professor Emeritus of Chemical Engineering at North Carolina State University, for his feedback on this paper.

\section{REFERENCES}

[1] Seely, B.E., "The Other Re-engineering of Engineering Education, 1900-1965," Journal of Engineering Education, Vol. 89, No. 7, 1999, pp. 285-294.

[2] Engineering Education for a Changing World, Engineering Deans Council and ASEE, 1994.

[3] Engineering Education: Designing an Adaptive System, National Research Council, 1995.

[4] Restructuring Engineering Education: A Focus on Change, Division of Undergraduate Education, National Science Foundation, 1995.

[5] Shaping the Future: New Expectations for Undergraduate Education in Science, Mathematics, Engineering, and Technology, Advisory Committee to the National Science Foundation, Directorate for Education and Human Resources, 1996.

[6] Transforming Undergraduate Education in Science, Mathematics, Engineering, and Technology, National Research Council, 1999.

[7] Reinventing Undergraduate Education: A Blueprint for America's Research Universities, The Boyer Commission on Educating Undergraduates in the Research University, Carnegie Foundation for the Advancement of Teaching, 1998.

[8] Matlin, M.W., Cognition, Forth Worth, Tex.: Harcourt Brace Jovanovich, 1989.

[9] Pinker, S., How the Mind Works, New York, N.Y.: W.W. Norton \& Company, 1997.

[10] Donald, J.G., Learning to Think: Disciplinary Perspectives, San Francisco, Cal.: Jossey-Bass, 2002.

[11] Gardner, H., Changing Minds: The Art and Science of Changing Our Own and Other People's Minds, Boston, Mass.: Harvard Business School Press, 2004.

[12] Boyer, E.L., Scholarship Revisited: Priorities of the Professoriate, Princeton, N.J.: The Carnegie Foundation for the Advancement of Teaching, 1990.

[13] Hayes, J.R., The Complete Problem Solver, Hillsdale, N.J.: Lawrence Erlbaum Associates, 1989.

[14] Chase, W.G., and Simon, H.A., "Perception in Chess," Cognitive Psychology, Vol. 4, 1973, pp. 55-81. 
[15] Hayes, J.R., "Cognitive Processes in Creativity," in Glover, J., Ronning, R., and Reynolds, C., eds., Handbook of Creativity, New York, N.Y.: Plenum, 1989.

[16] Ericsson, K.A., Krampe, R.T., and Tesch-Romer, C., "The Role of Deliberate Practice in the Acquisition of Expert Performance," Psychological Review, Vol. 100, 1993, pp. 363-406.

[17] Chi, M.T.H., Glaser, R., and Farr, M.J., The Nature of Expertise, Hillsdale, N.J.: Lawrence Erlbaum Associates, 1988.

[18] National Research Council, How People Learn: Brain, Mind, Experience, and School. Washington, D.C.: National Academy Press, 2000.

[19] Stice, J.E., Felder, R.M., Woods, D.R., and Rugarcia, A., "The Future of Engineering Education. Part IV: Learning How to Teach," Chemical Engineering Education, Vol. 34, No. 2, 2000, pp. 118-127.

[20] Bjorklund, S.A., Parente, J.M., and Sathianathan, D., "Effects of Faculty Interactions and Feedback on Gains in Student Skills," Journal of Engineering Education, Vol. 93, No. 2, 2003, pp. 153-160.

[21] Prince, M., "Does Active Learning Work? A Review of the Research," Journal of Engineering Education, Vol. 93, No. 3, July 2004, pp. 223-231.

[22] Walker, J.M.T., and King, P.H., "Concept Mapping as a Form of Student Assessment and Instruction in the Domain of Bioengineering," Journal of Engineering Education, Vol. 92, No. 2, 2003, pp. 167-179.

[23] Poli, C., Fisher, D., Pollatsek, A., and Woolf, B.P., "Design for Stamping: Identifying Pedagogically Effective Components in Multimedia Tutors and the Classroom," Journal of Engineering Education, Vol. 92, No. 3, 2003, pp. 227-237.

[24] Little, P., and Cardenas, M., "Use of 'Studio' Methods in the Introductory Engineering Design Curriculum," Journal of Engineering Education, Vol. 90, No. 3, 2001, pp. 309-318.

[25] Pimmel, R., "Cooperative Learning Instructional Activities in a Capstone Design Course," Journal of Engineering Education, Vol. 90, No. 3, 2001, pp. 413-421.

[26] Felder, R.M., and Brent, R., "Designing and Teaching Courses to Satisfy ABET Engineering Criteria," Journal of Engineering Education, Vol. 92, No. 1, 2003, pp. 7-25.

[27] Randolph, G.B., "Collaborative Learning in the Classroom: A Writing Across the Curriculum Approach," Journal of Engineering Education, Vol. 89, No. 2, 2000, pp. 119-122.

[28] Haller, C.R., Gallagher, V.J., Weldon, T.L., and Felder, R.M., "Dynamics of Peer Education in Cooperative Learning Workgroups," Journal of Engineering Education, Vol. 89, No. 3, 2000, pp. 285-293.

[29] McKeachie, W.J., Teaching Tips: Strategies, Research and Theory for College and University Teachers, Boston, Mass.: Houghton Mifflin, 1999.

[30] Gross Davis, B., Tools for Teaching, San Francisco, Cal.: Jossey-Bass, 1993.

[31] Kolb, D.A., Experiential Learning: Experience as the Source of Learning and Development, Englewood Cliffs, N.J.: Prentice-Hall, 1984.

[32] Zull, J., The Art of Changing the Brain, Bolton, Mass: Anker, 2003.

[33] Gardner, H., Multiple Intelligences: The Theory in Practice, New York, N.Y.: Basic Books, 1993.

[34] Svinicki, M.D, Learning and Motivation in the Postsecondary Classroom, Bolton, Mass.: Anker, 2004.

[35] bttp://www.ncsu.edwfelder-public/Learning_Styles.html.

[36] http://www.vark-learn.com/english/index.asp.

[37] Anderson, J.R., Cognitive Psychology and Its Implications, New York, N.Y.: W.H. Freeman and Company, 1990.

[38] Fink, L.D., Creating Significant Learning Experiences: An Integrated Approach to Designing College Courses, San Francisco, Cal.: Jossey-Bass, 2003.
[39] Bloom, B.S., ed., Taxonomy of Educational Objectives: The Classification of Educational Goals. Handbook I: Cognitive Domain. New York, N.Y.: David McKay, 1956.

[40] Anderson, L.W., and Krathwohl, D.R., eds., A Taxonomy for Learning, Teaching and Assessing: A Revision of Bloom's Taxonomy of Educational Objectives, New York, N.Y.: Longman, 2001.

[41] Johnson, D.W., Johnson, R.T., and Smith, K.A., Cooperative Learning: In Creating College Faculty Instructional Productivity, ASHEERIC Higher Education Reports, \#4, Washington, D.C.: School of Education and Human Development, George Washington University,'1991.

[42] Bonwell, C.C., and Eison, J.A., Active Learning: Creating Excitement in the Classroom, ASHE-ERIC Higher Education Reports, \#1, Washington, D.C.: George Washington University, 1991.

[43] Bean, J.C., Engaging Ideas: The Professor's Guide to Integrating Writing, Critical Thinking and Active Learning in the Classroom, San Francisco, Cal.: Jossey-Bass, 1996.

[44] Meyers, C., and Jones, T.B., Promoting Active Learning: Strategies for the College Classroom, San Francisco, Cal.: Jossey-Bass, 1993.

[45] Walvoord, B.E., and Anderson, V.J., Effective Grading: A Tool for Learning and Assessment, San Francisco, Cal.: Jossey-Bass, 1998.

[46] Wiggins, G., Educative Assessment: Designing Assessments to Inform and Improve Student Performance, San Francisco, Cal.: Jossey-Bass, 1998.

[47] Zubizaretta, J., ed., The Learning Portfolio: Reflective Practice for Improving Student Learning, Bolton, Mass.: Anker, 2004.

[48] Juwah, C., et al., Enhancing Student Learning Through Effective Formative Feedback, London, UK: Higher Education Academy, 2004.

[49] Michaelsen, L.K., Knight, A.B., and Fink, L.D., Team-Based Learning: A Transformative Use of Small Groups in College Teaching, Sterling, Va.: Stylus, 2004.

[50] Duch, B.J., Groh, S.E., and Allen, D.E., eds., The Power of Problem-Based Learning, Sterling, Va.: Stylus, 2001.

[51] Palmer, P.J., To Know as We Are Known: A Spirituality of Education, New York, N.Y.: Harper and Row, 1983.

[52] Palmer, P.J., The Courage to Teach: Exploring the Inner Landscape of a Teacher's Life, San Francisco, Cal.: Jossey-Bass, 1998.

[53] O'Reilley, M.R., The Peaceable Classroom, Portsmouth, N.H.: Boynton/Cook, 1993.

[54] O'Reilley, M.R., Radical Presence: Teaching as Contemplative Practice, Portsmouth, N.H.: Boynton/Cook, 1998.

[55] Howe, N., and Strauss, W., Millennials Rising: The Next Great Generation, New York, N.Y.: Vintage Books, 2000.

[56] Schor, J.B., Born to Buy: The Commercialized Child and the New Consumer Culture, New York, N.Y.: Scribner, 2004.

[57] Schmier, L., Random Thoughts: The Humanity of Teaching, Madison, Wis.: Atwood, 1995.

[58] Baxter Magolda, M., Creating Contexts for Learning and SelfAuthorship: Constructive-Developmental Pedagogy, Nashville, Tenn.: Vanderbilt University Press, 1999.

[59] Baxter Magolda, M., Making Their Own Way: Narratives for Transforming Higher Education to Promote Self-Development, Sterling, Va.: Stylus, 2001.

[60] Pascarella, E.T., and P.T. Terenzini, How College Affects Students, San Francisco, Cal.: Jossey-Bass, 1991.

[61] Astin, A.W., What Matters in College: Four Critical Years Revisited, San Francisco, Cal.: Jossey-Bass, 1993.

[62] Brawner, C.E., Felder, R.M., Allen, R., and Brent, R., "A Survey of Faculty Teaching Practices and Involvement in Faculty Development Activities," Journal of Engineering Education, Vol. 91, No. 4, 2002, pp. 393-396. 
[63] Fink, D., “President's Column,” POD Network News, Spring/Summer 2004, Published by the POD Network in Higher Education, P.O. Box 271370, Ft. Collins, CO.

[64] Gillespie, G.H., A Guide to Faculty Development, Bolton, Mass.: Anker, 2002.

[65] Schuster, J.H., and Wheeler, D.W., Enhancing Faculty Careers: Strategies for Development and Renewal, San Francisco, Cal.: Jossey-Bass, 1990.

[66] Brawner, C.E., Felder, R.M., Allen, R.H., and Brent, R., "How Important is Effective Teaching to Engineering Faculty and Administrators," Proceedings, 2002 ASEE Annual Conference, June 2002.

[67] See bttp://www.foundationcoalition.org/bome/foundationcoalition/ engineering_coalitions.html,

[68] Strader, R., Ambrose, S.A., and Davidson, C., "An Introduction to the Community of Professors," Journal of Engineering Education, Vol., 90, No. $1,2000$.

[69] See http://depts.washington.edu/celtweb/.

[70] See http://www.nae.edu/NAE/caseecomnerw.nsf.

[71] See http://www.nsf.gov/od/lpa/new/press/01/pr0170.htm.

[72] See $h t t p: / / w w w$ asee.org.

[73] See bttp://www.fie-conference.org.

[74] Kuh, G.D., and Whitt, E.J., The Invisible Tapestry: Culture in American Colleges and Universities, ASHE-ERIC Higher Education Report No.1. Washington, D.C.: Association for the Study of Higher Education, 1998.

[75] Schein, E.H., Organizational Culture and Leadership, San Francisco, Cal.: Jossey-Bass, 1992.

[76] Rousseau, D.M., "Assessing Organizational Culture: Quantitative and Qualitative Methods," in Schneider, B., ed., Organizational Climate and Culture, San Francisco, Cal.: Jossey-Bass, 1990.

[77] Glassick, C.E., Huber, M.T., and Maeroff, G.I., Scholarship Assessed: Evaluation of the Professoriate, San Franscisco, Cal.: Jossey-Bass, 1997.

[78] Felder, R.M., "The Scholarship of Teaching," Chemical Engineering Education, Vol. 34, No. 2, 2000, p. 144.

[79] Kotter, J.P., Leading Change, Boston, Mass.: Harvard Business School Press, 1996.

[80] Kezar, A.J., Understanding and Facilitating Organizational Change in the 21st Century: Recent Research and Conceptualizations, ASHE-ERIC Higher Education Report, Vol. 28, No. 4, 2001.

[81] Amon, C., and Ambrose, S.A., "Systematic Design of a Freshman Engineering Course," Journal of Engineering Education, Vol. 87, No. 2, 1997.

[82] Fink, D. Personal Communication. Interview with a Department Chair, October, 2004.

[83] Fink, D. Personal Communication. Interview with David Sabatini, October, 2004.

\section{AUTHORS' BIOGRAPHIES}

Dr. L. Dee Fink has served as director of the Instructional Development Program at the University of Oklahoma for twenty-five years. He is also the author of numerous publications on college teaching and faculty development, the most recent being Creating Significant Learning Experiences (JosseyBass, 2003). He is currently president of the premiere faculty development organization in North America, the POD Network in Higher Education.

Address: Instructional Development Program, University of Oklahoma, Hester Hall, Room 203, Norman, Oklahoma, 730190385; telephone: (405) 325-2323; fax: (405) 325-7402; e-mail: dfink@ou.edu.

Dr. Susan Ambrose is associate provost for Education, director of the Eberly Center for Teaching Excellence, and a teaching professor in the Department of History at Carnegie Mellon University. She was co-director of the NSF-sponsored Engineering Education Scholars Workshop (for five years) and has served as a visiting scholar for the ASEE. She is co-author of Journeys of Women in Engineering and Science: No Universal Constants (1997), The Women's Guide to Navigating the Ph.D. in Engineering and Science (2001), and The New Professor's Handbook: $A$ Guide to Teaching and Research in Engineering and Science (1994).

Address: 127 Cyert Hall, Carnegie Mellon University, 5000 Forbes Avenue, Pittsburgh, PA 15213; telephone: (412) 268-2855; fax: (412) 268-5701; e-mail: sa0n@andrew.cmu.edu.

Dr. Daniel (Dan) W. Wheeler is professor of Leadership Studies and former coordinator of the Office of Professional and Organizational Development at the University of NebraskaLincoln. He has published extensively on faculty development, chairing departments, and leadership. He is co-author of The Academic Chairperson Handbook (1990) and Enhancing Faculty Development: Strategies for Development and Renerwal (1990). He is a past president (1992) of the Professional and Organizational Development (POD) Network in Higher Education and recipient of the prestigious Spirit of POD Award. Presently he teaches and consults in the United States and internationally in the areas of leadership and organizational effectiveness.

Address: Department of Ag Leadership, Education and Communication, $300 \mathrm{Ag}$ Hall, Lincoln, NE 68583-0709, telephone: (402) 472-4749; fax: (402) 472-5863; e-mail: DWheeler1@ unl.edu. 